Proc. Estonian Acad. Sci. Geol., 2002, 51, 4, 241-258

\title{
Vegetation history and human impact in the Parika area, Central Estonia
}

\author{
Eve Niinemets, Leili Saarse, and Anneli Poska \\ Institute of Geology, Tallinn Technical University, Estonia pst. 7, 10143 Tallinn, Estonia; \\ Even@ut.ee; Saarse@gi.ee; Poska@gi.ee \\ Received 12 February 2002, in revised form 29 April 2002

\begin{abstract}
In order to reconstruct the Holocene vegetation history of the northern part of the Võrtsjärv Lowland, a sediment sequence was collected from the Parika bog and analysed for fossil pollen. Peat started to accumulate at the beginning of the Holocene. Peat increment has been more intensive since 1400 uncalibrated ${ }^{14} \mathrm{C}$ BP (peat increment $1.47-1.60 \mathrm{~mm} \mathrm{yr}^{-1}$ ) and slowest between 6600 and $5000 \mathrm{BP}\left(0.40 \mathrm{~mm} \mathrm{yr}^{-1}\right)$. Recorded vegetation development started with open birch-pine woodland. Temperate mixed forest was established before $7600 \mathrm{BP}$. The proportion of broad-leaved forest was modest throughout the Holocene. Specific to the Parika diagram is the high frequency of spruce since 4800 BP. Palynological and archaeological records indicate that the Võrtsjärv Lowland was inhabited during the Mesolithic. During the Late Bronze Age the area was rather open. However, compared to North Estonia, agricultural land-use was delayed about 1000 years; it was restricted in area and discontinuous. Cereal cultivation (Hordeum and Triticum) started at the end of the Pre-Roman Iron Age. The Parika bog is considered to be a new biostratigraphic reference site in the northern part of the Võrtsjärv Lowland.
\end{abstract}

Key words: pollen analysis, cultural history, chronology, vegetation history, land-use.

\section{INTRODUCTION}

Several latest publications have highlighted the vegetation history of North and West Estonia (Poska \& Königsson 1996; Veski \& Lang 1996; Veski 1998; Poska \& Saarse 1999; Saarse et al. 1999a), but Central and South Estonia have received less attention (Mäemets 1983; Saarse 1994; Punning et al. 1995; Saarse \& Rajamäe 1997). The role of human activity affecting the landscape change in the latter region is poorly documented (Ilves \& Mäemets 1987; Pirrus et al. 1993) though, recently there has been an increased interest in this particular aspect (Poska \& Saarse 1996; Kihno \& Valk 1999; Laul \& Kihno 1999a, 1999b). 
This study was aimed at collecting biostratigraphical material from the northern part of the Võrtsjärv Lowland. It was once an important Mesolithic habitation centre, but the Holocene reference sites are absent there. The main objective of the present paper is to reconstruct the long-term vegetation and land-use history of Central Estonia, to examine the human impact impressions on the new detailed and well-dated pollen diagram, to compare our results with the published biostratigraphic and archaeological records. The Parika bog was chosen as the study area because biostratigraphic reference sites are absent in this particular region and peat is a good geological archive to reconstruct the environmental changes. Sphagnum peat is regarded as the best material for radiocarbon dating (Olsson 1986).

\section{STUDY AREA}

Parika is a raised bog in the northwestern part of the Võrtsjärv Lowland $\left(58^{\circ} 30^{\prime} \mathrm{N}, 25^{\circ} 47^{\prime} \mathrm{E}\right)$, Central Estonia (Fig. 1A), in a NW-SE trending depression between the eastern slope of the Sakala Upland and the Kolga-Jaani drumlin field (Fig. 1C). The total area of the bog is $34 \mathrm{~km}^{2}$, of that fen makes up $14 \mathrm{~km}^{2}$, transitional bog $1 \mathrm{~km}^{2}$, and raised bog $19 \mathrm{~km}^{2}$ (Orru 1995). The elevation of the bog surface is uneven, between 45 and $50 \mathrm{~m}$ a.s.l. The Viljandi-Põltsamaa road, lakes Parika $\left(1.14 \mathrm{~km}^{2}\right)$ and Väikejärv $\left(0.05 \mathrm{~km}^{2}\right)$ and several mineral islands $\left(0.5 \mathrm{~km}^{2}\right)$ divide up the bog. The eastern and southwestern shores of Lake Parika support pine, common to the transitional bog. Fen vegetation spreads widely in the NW and SE parts as sprouted grassland (Orru 1995). More than half of the peat is composed of Sphagnum peat, succeeded by Sphagnum-Eriophorum, Carex-Phragmites, and well-decomposed woody fen peat with a maximum thickness of $10 \mathrm{~m}$ (Orru 1995). A nature reserve was established in the central part of the Parika bog for the preservation of a mire ecosystem. Most of the surroundings is covered by pine-birch-spruce forest integrating patches of more open landscape.

The northern part of the Võrtsjärv Lowland is rich in archaeological monuments (Jaanits 1959; Moora 1968; Jaanits \& Ibius 1973; Jaanits et al. 1982; Kiristaja et al. 1998; Kriiska 2001; Fig. 1B). Archaeological records show that this area was inhabited between 7000 and 4000 BC (Jaanits 1968). The indented shoreline of Lake Big Võrtsjärv (in the sense of Orviku 1973) with several islands offered suitable living conditions to the hunters, fishermen, and gatherers who were well adapted to the coastal environment and riverbanks. The first settlers were probably mobile and relocated according to season and availability of food. At present, twelve settlement sites (camps), typologically dated to the Mesolithic Kunda culture are known from this region (Jaanits et al. 1982; Kiristaja et al. 1998). Archaeological sites dated to this period, such as Siimusaare, Moksi, Umbusi, Leie, Lalsi, etc., have yielded evidence of settlers not knowing arable farming. Osteological data demonstrate utilization of a wide range of game, including small game, waterfowl and fish (Jaanits \& Ilomets 1983). The artefacts 


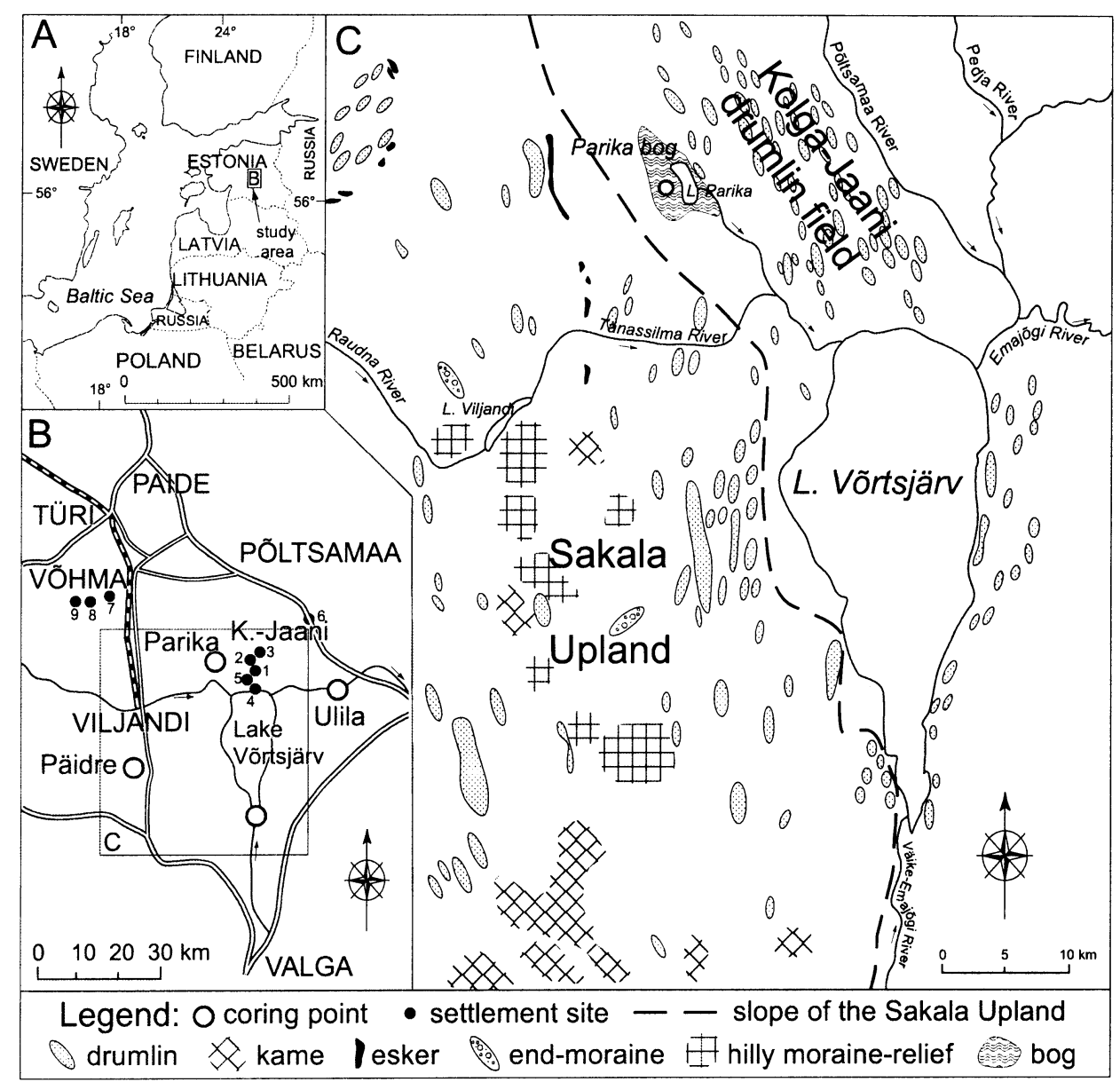

Fig. 1. (A) Location of the study area. (B) Location of the sites analysed for pollen and discussed in the text; archaeological settlement sites: 1, Lalsi I-II; 2, Lalsi III-IV; 3, Siimusaare; 4, Moksi; 5, Leie; 6, Umbusi; 7, Jälevere; 8, Tamme; 9, Lepakose. (C) Topography of the vicinity of the Parika bog; the sampling site is indicated.

related to the Early Bronze Age are scanty and settlement sites are not known. The population density increased during the Roman Iron Age, the settlement centre relocated to the Sakala Upland, and the Parika area became peripheral (Moora 1968). Archaeologists suggest some decrease in population density during the Migration Period and the Viking Age due to battles and attacks, which led local people to erect strongholds. The northern part of the lowland stayed sparsely populated up to the beginning of the second millennium AD. Only very few stone grave and stray finds from this period are known. The size of the population in the Kolga-Jaani region was significantly affected by the plague and the attacks 
in 1212 AD (Tarvel 1993), the Livonian War (1582-1623 AD), and the Northern War (1700-1721 AD). The population density grew rapidly during the 18th century. In 1771, there were 123 people per one plot of arable land at Kolga-Jaani (Jaanits \& Ibius 1973).

\section{MATERIAL AND METHODS}

In 1998, a sedimentary sequence from the Parika bog was collected with a Belarus peat sampler from the deepest, western part of the bog, where the peat was $925 \mathrm{~cm}$ thick and the bog surface was at a height of c. $50 \mathrm{~m}$ a.s.l. Pollen and loss-on-ignition analyses, and the ${ }^{14} \mathrm{C}$ dating were used to examine the Late Glacial and Holocene environmental changes and human impact.

For pollen preparation and analysis a standard method described by Erdtman (1936) and Fægri \& Iversen (1989) was used, 700-1000 grains of arboreal pollen (AP) were counted at each level, except the bottommost mineral portion of the sediment. The basis for the percentage calculations was the sum of terrestrial pollen; the percentages of other microfossils were calculated from the basic pollen sum. The summary pollen diagram was designed with TILIA and TILIA.GRAPH programs (Grimm 1992). The human impact diagram was constructed on the basis of the selection of identified nonarboreal pollen (NAP), yielding information about the changing landscape utilization practices. The herb taxa were grouped according to Behre (1981, 1988), Berglund \& Ralska-Jasiewiczowa (1986), Hicks (1990), Berglund (1991), and Poska (2001) into eight land-use categories.

Numerical zonation of the pollen and human impact diagrams was made using the "psimpoll" program by the optimal splitting by the sum-of-squares method (Bennett 1996). The local pollen assemblage zones were determined on the basis of all identified taxa. The human impact zones were specified on the basis of taxa connected with human impact. Still, Calluna and Cyperaceae were excluded from the pollen sum to minimize the shadowing effect of the extra-local communities.

To determine organic matter, carbonate and terrigenous fractions, loss-onignition at 500 and $825^{\circ} \mathrm{C}$ of $1-\mathrm{cm}$-thick samples at $10 \mathrm{~cm}$ interval was used. To obtain independent chronologies, conventional ${ }^{14} \mathrm{C}$ radiocarbon dating of bulk peat samples was performed at the Institute of Geology, Tallinn Technical University.

The ${ }^{14} \mathrm{C}$ age was determined for eight bulk peat samples (Table 1; Fig. 2). All radiocarbon dates are consistent with the pollen stratigraphy and applied to calculate the sample age and peat increment. Both, uncalibrated and calibrated radiocarbon dates are given to facilitate the comparison of the present and earlier published biostratigraphical material. For the same reason in the chapter on pollen stratigraphy and vegetation development uncalibrated radiocarbon years are used, but in the chapter on human impact calibrated radicarbon years are employed. Radiocarbon dates were calibrated according to Stuiver et al. (1998) at 1 sigma and expressed as calendar years $\mathrm{BC}$ and $\mathrm{AD}$. 
Table 1. Radiocarbon dates and the accumulation rate of the peat from the Parika bog

\begin{tabular}{c|c|c|c|c|l}
\hline $\begin{array}{c}\text { Depth, } \\
\text { cm }\end{array}$ & $\begin{array}{c}{ }^{14} \mathrm{C} \text { age, } \\
\text { BP }\end{array}$ & Lab. index & $\begin{array}{c}\text { Calibrated age, } \\
\text { AD/BC }\end{array}$ & $\begin{array}{c}\text { Peat } \\
\text { increment, } \\
\mathrm{mm} \mathrm{yr}^{-1}\end{array}$ & Material \\
\hline $100-110$ & $770 \pm 50$ & Tln-2295 & $1221-1283 \mathrm{AD}$ & 1.47 & Sphagnum peat \\
$200-210$ & $1425 \pm 45$ & Tln-2290 & $601-657 \mathrm{AD}$ & 1.60 & Sphagnum peat \\
$300-310$ & $2215 \pm 55$ & Tln-2292 & $363-203 \mathrm{BC}$ & 1.10 & Sphagnum peat \\
$400-410$ & $3115 \pm 65$ & Tln-2293 & $1489-1265 \mathrm{BC}$ & 0.91 & Sphagnum-Eriophorum peat \\
$550-560$ & $5030 \pm 60$ & Tln-2298 & $3941-3713 \mathrm{BC}$ & 0.61 & Carex peat with Phragmites \\
$620-630$ & $6665 \pm 60$ & Tln-2294 & $5657-5531 \mathrm{BC}$ & 0.40 & Carex peat with Phragmites \\
$720-730$ & $7940 \pm 65$ & Tln-2296 & $7031-6699 \mathrm{BC}$ & 0.79 & Phragmites-Carex peat \\
$820-830$ & $9000 \pm 75$ & Tln-2297 & $8287-8199 \mathrm{BC}$ & 0.73 & Phragmites-Carex peat
\end{tabular}

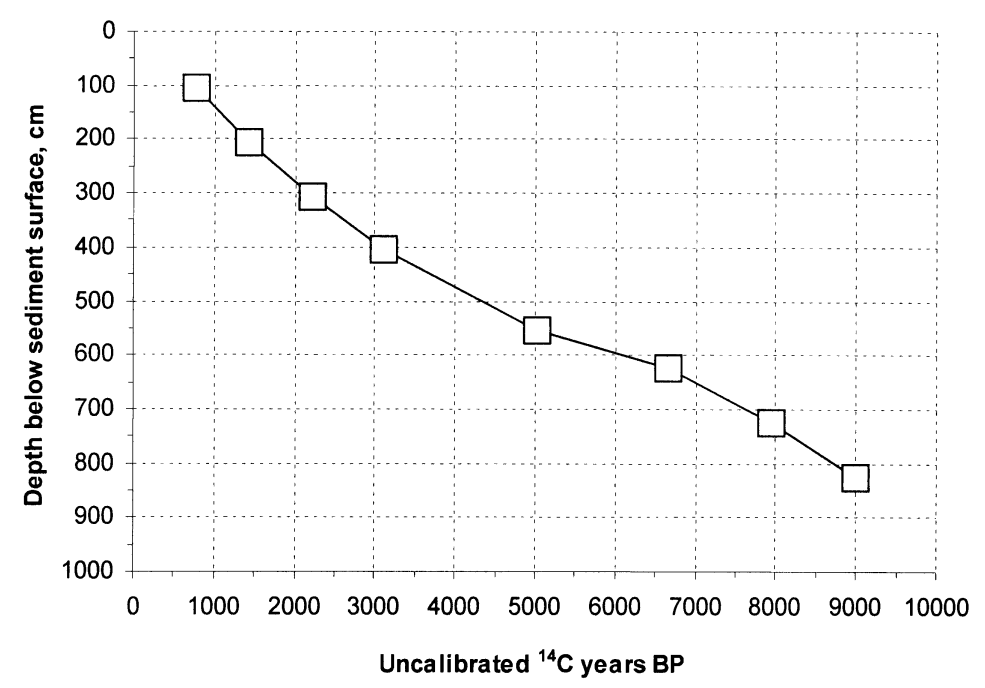

Fig. 2. Age-depth plot for the Parika bog. The ages of the dated levels are indicated by squares.

\section{RESULTS AND DISCUSSION}

\section{Sediment lithology}

Sediment lithology of the studied sequence is displayed in Fig. 3. The basal silt $(982-925 \mathrm{~cm})$ contains up to $14 \%$ organic matter and up to $16 \%$ carbonates. Minerogenic deposits are covered by well decomposed fen peat $(925-800 \mathrm{~cm})$, Phragmites-Carex $(800-650 \mathrm{~cm})$, and Carex peat with Phragmites remains $(650-500 \mathrm{~cm})$. These beds are characterized by stable organic matter $(92-96 \%)$ and low terrigeneous load. At the bottom of fen peat the content of organic matter slightly decreases to $72 \%$ and that of terrigeneous fraction increases $27 \%$. The 


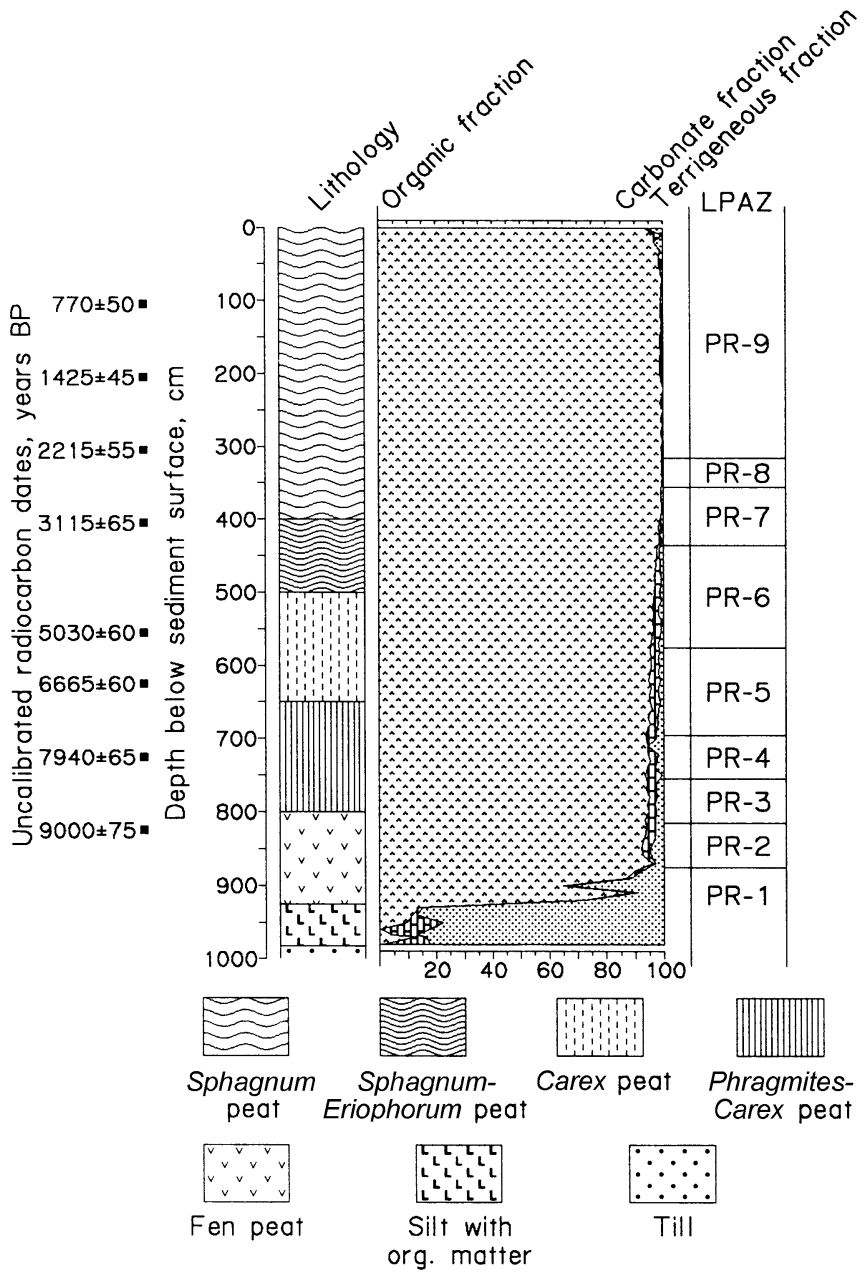

Fig. 3. Sediment lithology and contents of organic, carbonate, and terrigeneous fractions in the main core of the Parika bog. LPAZ - local pollen assemblage zone.

carbonate content is commonly less than 4\%. The uppermost SphagnumEriophorum $(500-400 \mathrm{~cm})$ and Sphagnum peat $(400-0 \mathrm{~cm})$ have a high and stable organic matter content (97-99\%), with the exception of the topmost layer, where the organic matter decreases to $94 \%$, mostly on account of the terrigeneous fraction. The increment of the Sphagnum peat is lowest $\left(0.40 \mathrm{~mm} \mathrm{yr}^{-1}\right)$ between 625 and $555 \mathrm{~cm}(6600-5000 \mathrm{BP})$ and highest $\left(1.47-1.60 \mathrm{~mm} \mathrm{yr}^{-1}\right)$ in the topmost part of peat, at $210-0 \mathrm{~cm}$ (from $1400 \mathrm{BP}$ up to the present). Why the peat increment is slowest during the Late Atlantic is hard to explain, as generally climate was warm and humid. One possible reason could be decrease in groundwater table indicated by reconstructed lake level lowering in Estonia between 6500 and 5500 BP (Saarse \& Harrison 1992). High peat increment in the 
topmost beds is partly explained by poor compaction of the topmost peat in combination with the climatic change in Estonia from continental to more maritime at least during the last 150 years (Tarand \& Kallaste 1998).

\section{Pollen stratigraphy and vegetation development}

Nine local pollen assemblage zones were recognized by numerical zonation (Table 2, Fig. 4a,b). At the end of the Late Glacial and beginning of the Holocene (PR-1 and 2; ?-8850 uncal. BP), the pollen assemblage with high Cyperaceae

Table 2. The biostratigraphical division of the main pollen diagram. LPAZ-local pollen assemblage zone

\begin{tabular}{|c|c|c|}
\hline $\begin{array}{c}\text { LPAZ/ } \\
\text { Depth, cm }\end{array}$ & $\begin{array}{l}\text { Uncal. }{ }^{14} \mathrm{C} \\
\text { age, BP }\end{array}$ & Description \\
\hline $\begin{array}{l}\text { PR-1 } \\
930-875\end{array}$ & ?-9500 & $\begin{array}{l}\text { Extremely high NAP content, mainly Cyperaceae. AP consists mostly of } \\
\text { Betula and Pinus pollen. }\end{array}$ \\
\hline $\begin{array}{l}\text { PR-2 } \\
875-815\end{array}$ & $9500-8850$ & $\begin{array}{l}\text { Betula pollen dominates and reaches a maximum, Pinus is rising. Salix has } \\
\text { its maximum. NAP amount is still high with Cyperaceae and Poaceae } \\
\text { dominating. At first Ulmus and Alnus, later Corylus occur. }\end{array}$ \\
\hline $\begin{array}{l}\text { PR-3 } \\
815-755\end{array}$ & $8850-8250$ & $\begin{array}{l}\text { Pinus pollen increases, Betula decreases substantially. Occasional Picea, } \\
\text { Tilia, and Fraxinus pollen is present. NAP has a peak on account of Poaceae, } \\
\text { which reaches its maximum. }\end{array}$ \\
\hline $\begin{array}{l}\text { PR-4 } \\
755-695\end{array}$ & $8250-7500$ & $\begin{array}{l}\text { At PR lower limit Pinus pollen reaches a maximum and starts to decrease } \\
\text { along with increase in Alnus and Ulmus. Tilia appears, Quercus and Picea } \\
\text { occur in low values. The total AP frequency is unstable. }\end{array}$ \\
\hline $\begin{array}{l}\text { PR-5 } \\
695-575\end{array}$ & $7500-5450$ & $\begin{array}{l}\text { High appearance of Corylus and Ulmus, later Tilia. Substantial increase in } \\
\text { Quercetum mixtum (QM) pollen. Significant rise in Picea at PR upper limit. }\end{array}$ \\
\hline $\begin{array}{l}\text { PR-6 } \\
575-435\end{array}$ & $5450-3400$ & $\begin{array}{l}\text { QM maximum. Picea increases. NAP composition changes drastically. } \\
\text { Cyperaceae and Polypodiaceae diminish substantially, substituted by } \\
\text { Sphagnum and its satellites and Calluna vulgaris. The representation of } \\
\text { NAP has diminished. }\end{array}$ \\
\hline $\begin{array}{l}\text { PR-7 } \\
435-355\end{array}$ & $3400-2600$ & $\begin{array}{l}\text { Picea dominates; QM decreases considerably on account of Ulmus, Tilia, } \\
\text { and Fraxinus. Total AP reaches a maximum. In the NAP composition the } \\
\text { proportion of aquafilous taxa has diminished. }\end{array}$ \\
\hline $\begin{array}{l}\text { PR-8 } \\
355-315\end{array}$ & $2600-2300$ & $\begin{array}{l}\text { Betula, Alnus, and Corylus pollen decreases. NAP rises considerably, } \\
\text { especially Calluna and Vaccinum. }\end{array}$ \\
\hline $\begin{array}{l}\text { PR-9 } \\
315-0\end{array}$ & $\begin{array}{l}2300- \\
\text { up to } \\
\text { present }\end{array}$ & $\begin{array}{l}\text { Betula and Pinus are dominant, Picea remains as high as Alnus. QM } \\
\text { decreases to the content similar to that of today. Corylus, Ulmus, and } \\
\text { Quercus are present. NAP frequency rises considerably in the top of the } \\
\text { sequence. The cultural indicators are constantly present. }\end{array}$ \\
\hline
\end{tabular}




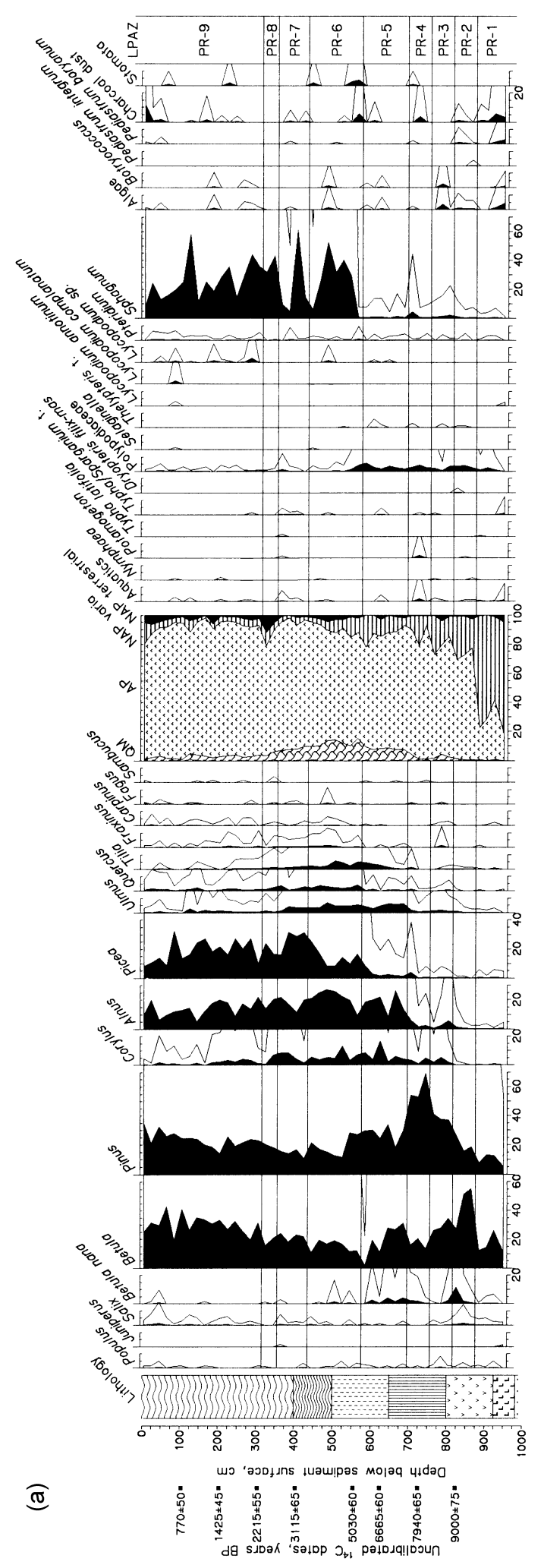




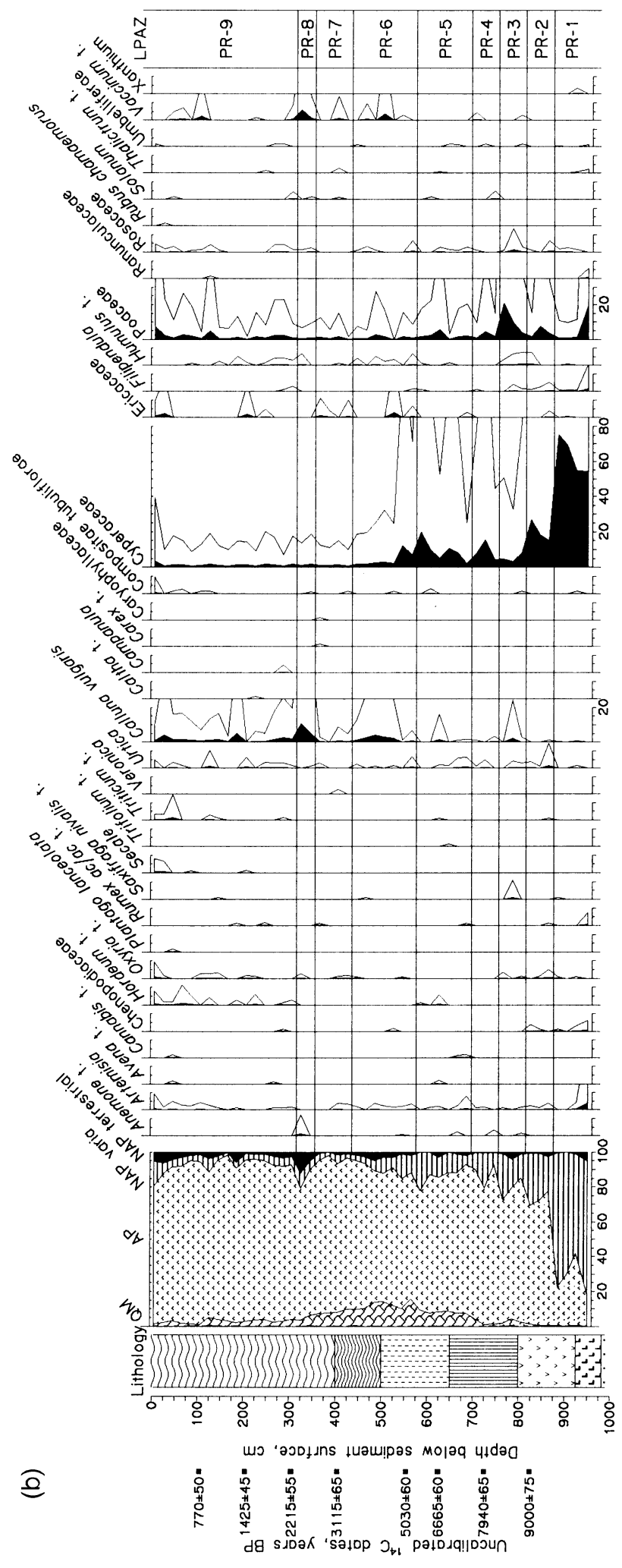

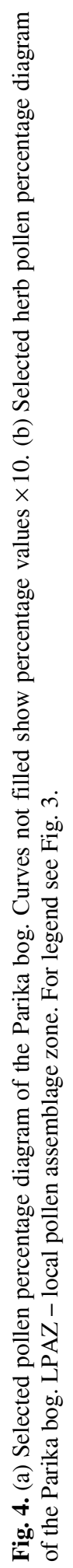


(Fig. 4b) and Pediastrum (Fig. 4a) suggests waterlogged conditions and the existence of a lakeshore not far away, which in the middle of PR-1 turned to fen. Open birch and pine woods dominated, with scattered willow. At first Ulmus and Alnus, later Corylus occurred. High representation of Betula nana at the end of PR-2 (Fig. 4a) is remarkable. The vegetation at $8850-8250$ BP (PR-3) was characterized by a marked dominance of the light-demanding Pinus (Fig. 4a). The forest succession favoured Corylus and Ulmus, but due to unfavourable edaphic conditions they probably became integrated members of the forest rather than forming pure stands in the area. At 8250-5450 BP (PR-4 and PR-5), the share of broad-leaved trees $(\mathrm{QM})$ increased and arboreal vegetation became more variable. At c. $7900 \mathrm{BP}$, Alnus quickly expanded due to favourable local topography swampy areas. With the immigration of Tilia, all broad-leaved trees had arrived, except Carpinus. The proportion of QM stayed low throughout the Middle Holocene, probably because of the lack of suitable habitats and progressive paludification of the Vorrtsjärv Lowland. Picea immigrated to the area about 7700-7600 BP and spread at 6300-6200 BP, which is in accordance with the earlier obtained pollen records (Saarse et al. 1999b). With the spread of Picea, both Pinus and Betula obtained a competitor for habitat.

At the beginning of PR-6 (5450-3400 BP), Fraxinus and Carpinus immigrated to the area, QM had two pronounced maximums, at 5300 and $4500 \mathrm{BP}$, and a distinct Ulmus decline occurred at 4250 BP (Fig. 4a). At the beginning of PR-6 (Fig. 4a,b), a rapid and distinct change took place in the development of the investigated basin. The Cyperaceae pollen and Polypodiaceae spores decreased substantially and were substituted by Ericaceae pollen and Sphagnum spores, marking the beginning of the raised bog stage.

In PR-7 (3400-2600 BP), Picea spread abundantly, with its maximum between 3300 and $2300 \mathrm{BP}$, followed by a decline of mixed oak forests. This is usually explained with the deterioration of climate and degradation of soils. The last period in the forest history (PR-8 and PR-9; 2600 BP - up to present) is expressed by a decreasing content of temperate trees and return to the pine-birch-spruce woodland. The vegetation composition remained quite stable; only a slight increase in Betula and Pinus and a general decrease in Picea, Alnus, and Corylus and trees of mixed oak forest were observed. By today, almost all QM stands have been cut down, only Fraxinus forms groves on the slopes of the ancient valleys of the Sakala Upland (Saarse et al. 1995).

Apart from the drastic and sudden changes in herb and grass assemblages due to by the natural development of the bog, also some long-term vegetation trends are noticed, probably caused by human impact in combination with natural processes like climate and soil deterioration. A comparison of the Betula and Corylus pollen percentages shows the prevalence of Betula over Corylus, especially from 2500 BP (Pre-Roman Iron Age). A similar trend was observed in southern Sweden (Berglund 1991; Lagerås 1996). This trend has been more pronounced since the pasture expansion and is explained as a combined effect of natural and anthropogenic influence (Lagerås 1996). 


\section{Environmental changes}

In the studied part of the Parika bog three main development stages can be followed: fen, transitional and raised bog. During the fen stage well-decomposed woody peat, during the transitional stage Phragmites-Carex and Carex peat with Phragmites remains, and during the raised bog stage Sphagnum-Eriophorum and Sphagnum peat were formed. It appears that every next stage in the bog history was longer than the previous one. So, the fen stage lasted about 1200 years, transitional stage 3800 years, while the last, bog stage has already lasted over 5000 years, and is still continuing.

The most drastic environmental changes traced on the pollen diagram occurred before $9500 \mathrm{BP}$ (interpolated age) and 5400-5300 BP. By about $9500 \mathrm{BP}$ the shallow water body which filled the Parika basin was overgrown and minerogeneous sedimentation replaced by organogeneous one. The high frequency of Cyperaceae diminished drastically, giving ground to Poaceae and other terrestrial herbs. The AP:NAP ratio became distorted in favour of AP (Fig. 4a). The lake in the Parika basin was obviously not connected with the Ice Võrtsjärv in the sense of Orviku (1973), as the Parika threshold at $45 \mathrm{~m}$ exceeds the suggested Ice Võrtsjärv water level by $2-3 \mathrm{~m}$. Another drastic change in the pollen composition is connected with the development of the bog itself - with its turn to the raised bog stage. This was accompanied with a sharp increase in the Sphagnum spores, a decrease in the total NAP, and an increase in the Alnus pollen frequencies (Fig. 4a).

\section{Human impact}

Eight land-use phases have been distinguished in the human impact diagram (Fig. 5). When reconstructing human impact on the basis of pollen record from a rather large bog like Parika, it is important to know that indications of forest disturbance may not be clearly registered in the pollen diagram. Still, the Parika pollen diagram displays some evidence of vegetation disturbance during Mesolithic time (8000-4900 BC). The early and late Mesolithic part of the mentioned diagram (PRH-2 and PRH-3; Table 3) reveals fluctuating and markedly reduced AP values (Fig. 4a, PR-3 to PR-5), caused by the natural development of the bog in combination with climate and soil deterioration. Still, the high proportion of Poaceae and the ruderal (especially Urtica) pollen may have been facilitated by forest disturbance, attesting well with archaeological records of the colonization of the Võrtsjärv Lowland during Mesolithic time (Jaanits 1968). At the end of the Mesolithic, settlers most probably relocated close to food resources, along the contemporary riverside and lakeshore. Due to rapid paludification of the area, these settlement sites were probably short-lived and soon buried by peat. Obviously, for this reason the traces of the Neolithic forest disturbance and Bronze Age arable farming are rather weak in the Parika diagram (Fig. 5, PRH-4). The anthropogenic indicator graphs diminish slightly, AP recovers distinctly from the previous fall, and 


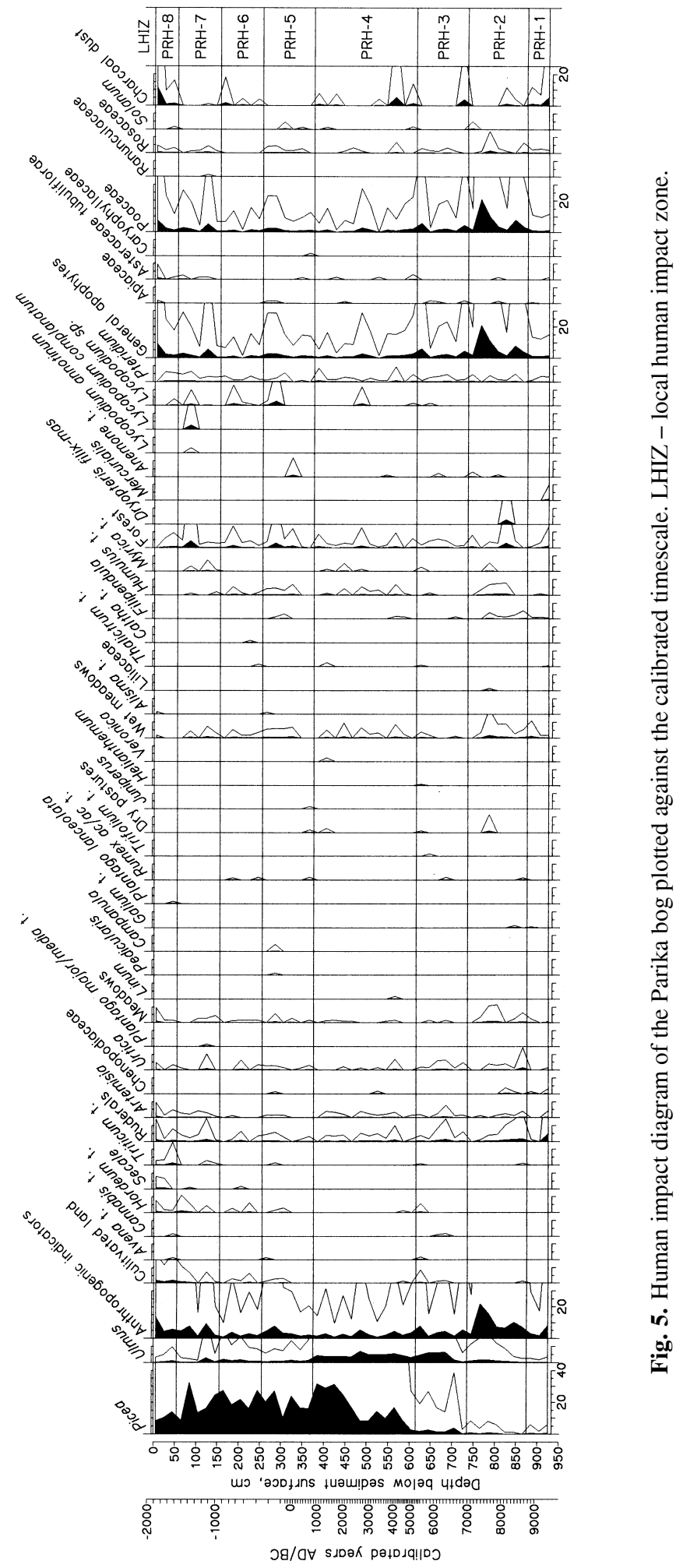


the NAP amount reaches almost a minimum (Fig. 3, PR-6). This points to the forest regeneration in the area. Peaks in the curves of Betula, Alnus, and Salix (quickly regenerating and early successional trees) indicate overgrowth of the earlier opened up landscape (Fig. 4a, PR-6 and PR-7). One reasonable explanation is the transition to farming and relocation of people from hunting and gathering areas to areas with soils suitable for agriculture (Lang 1999). The tillage here did not give as good results as in the areas with light calcareous soils in North Estonia. The other explanation is that the settlers on the Võrtsjärv Lowland were mostly orientated to cattle breeding, and less to arable farming (Jaanits 1968). After the second Ulmus decline the area around the Parika bog was more intensively used as wooded pasture (Fig. 5). From the Late Bronze Age onwards the area was rather open, but the agricultural land-use was still restricted and discontinuous.

Table 3. The biostratigraphical division of the human impact diagram. LHIZ - local human impact zone

\begin{tabular}{c|c|c}
\hline $\begin{array}{c}\text { LHIZ/ } \\
\text { Depth, } \\
\mathrm{cm}\end{array}$ & $\begin{array}{c}\mathrm{Cal}{ }^{14} \mathrm{C} \text { age, } \\
\mathrm{BC} / \mathrm{AD}\end{array}$ & Description \\
\hline
\end{tabular}

PRH-1 ?-8880 BC Low frequencies of meadow, forest, and general apophyte (Poaceae) 930-875 pollen. Very high proportion of wet meadow taxa (Cyperaceae).

PRH-2 8880-7000 BC At certain levels significant frequency of ruderal, meadow, and forest 875-735 taxa. Wet meadow indicators are constantly present. General apophytes make a maximum on account of Poaceae. Charcoal particles are sporadic.

PRH-3 7000-5430 BC Impressive decline in meadow, wet meadow, and general apophyte 735-615 curves. Charcoal occurs sporadically.

PRH-4 5430-1010 BC Slight decrease in all defined land-use groups and charcoal particles. 615-375 First Ulmus decline at about 2700 BC. Expansion of Picea.

PRH-5 1010-220 BC Final Ulmus decline. Opening up of forest. Rise in summary anthro375-255 pogenic indicators curve. Sporadic Hordeum and Triticum pollen. Charcoal particles are not identified.

PRH-6 220 BC- Picea is unstable. Decrease in meadow, wet meadow, forest taxa, and 255-155 $900 \mathrm{AD} \quad$ general apophytes. Hordeum pollen is more frequent.

PRH-7 900-1500 AD Well-developed cultivated plants and ruderal curves. Sharp rise of 155-55 Poaceae and summary anthropogenic indicators graphs. Charcoal particles are not identified.

PRH-8 1500-1950 AD Clear increase in all defined land-use groups. The cultivated plants are 55-0 present in considerably high values. 
Within 300-350 AD (Roman Iron Age; Fig. 5, PRH-5) the population density increased. Triticum and Hordeum were cultivated, which is considerably later than in the northern coastal areas (Veski \& Lang 1996; Poska \& Saarse 1999). The cultivation and probably settlement density diminished during the Migration Period (400-500 AD) and the Viking Age (800-900 AD), as pollen of cereals decreased considerably, and Picea and Ulmus recovered slightly. The agrarian activities intensified from AD 1100 (Fig. 5, PRH-7), with a small decline at the end of the Late Iron Age. At about 1200-1250 AD all cereals disappear to reappear later and with higher values. Diminishing of meadow plants and the formation of the Picea peak hint that pastoral farming also decreased or relocated to some distance from the Parika bog. The collapse in arable farming was obviously caused by battles and plague, which, according to written sources befell in 1212 (Jaanits \& Ibius 1973).

\section{CONCLUSIONS}

A new biostratigraphic reference site, the Parika bog, for the northern part of the Võrtsjärv Lowland was suggested and studied. Vegetation development in the vicinity of the Parika bog started at the end of the Late Glacial with open Betula forest, which gradually became denser. At about 8800 BP Pinus became a dominating species. Soon after, at about $7600 \mathrm{BP}$, many deciduous trees immigrated to form temperate mixed forests. The proportion of broad-leaved forest was modest throughout the Holocene. Specific to the Parika area is the high frequency of Betula nana pollen (up to $6000 \mathrm{BP}$ ) and Picea (since $4800 \mathrm{BP}$ ). An extremely high amount of sedges is observed in the lower part of the diagram.

The present study also highlights the peat increment trend. The exact time of the start of the paludification in the vicinity of Parika is not known, but pollen correlation with the stratigraphic chart suggests it started in the Preboreal, at the beginning of the Holocene. Peat increment has been the most intensive since $1400 \mathrm{BP}$, partly due to slight compaction of the uppermost layer, and was slowest between 6600 and $5000 \mathrm{BP}\left(0.40 \mathrm{~mm} \mathrm{yr}^{-1}\right)$.

The Mesolithic Kunda culture settlers left few traces in the environmental history. Still, the increased proportion of ruderals, especially Urtica, is significant. The Ulmus decline at 4200-4300 BP is registered later than in the other areas of Central Estonia and therefore can be assigned to forest clearance. The area around the Parika bog was more intensively used after the second local Ulmus decline at about $2900 \mathrm{BP}$, first as wooded pasture, and later for arable farming. From the Late Bronze Age onwards, the area was rather open, but the agricultural land-use was still limited and discontinuous. The cultivation and probably settlement density declined during the Migration Period (400-500 AD) and the Viking Age (800-900 AD) and at the end of the Late Iron Age, about 1200 AD. The meadow plants also diminished, and Picea generated a peak. This suggests that pastoral farming also decreased or relocated to some distance from the Parika bog. Cereal 
cultivation (Hordeum and Triticum) started during the Roman Iron Age, being first rather restricted, but expanded during the Middle Ages. Slash-and-burn cultivation, if although occurred, was probably introduced during the Iron Age. So, the agrarian expansion into the Võrtsjärv Lowland took place about 1000 years later than into North Estonia.

\section{ACKNOWLEDGEMENTS}

We wish to thank Atko Heinsalu and Siim Veski who assisted on the field and took the core. We are indebted to Prof. Anto Raukas and two anonymous referees for critical remarks on the manuscript. Financial support of the governmental target project 0331758s01 and Estonian Science Foundation grant No. 4963 is appreciated.

\section{REFERENCES}

Behre, K. E. 1981. The interpretation of anthropogenic indicators in pollen diagrams. Pollen et Spores, 23, 225-245.

Behre, K. E. 1988. The role of man in European vegetation history. In Vegetation History. Handbook of Vegetation Science 7 (Huntley, B. \& Webb III T., eds.), pp. 633-672. Kluwer, Dordrecht.

Bennett, K. 1996. Determination of the number of zones in a biostratigraphical sequence. New Phytologist, 132, 155-170.

Berglund, B. E. (ed.). 1991. The Cultural Landscape During 6000 Years in Southern Sweden - the Ystad Project. Ecol. Bull., 41, Munksgaard, Copenhagen.

Berglund, B. E. \& Ralska-Jasiewiczowa, M. 1986. Pollen analyses and pollen diagrams. In Handbook of Holocene Palaeoecology and Palaeohydrology (Berglund, B. E., ed.), pp. 455-484. John Wiley, Chichester.

Erdtman, G. 1936. New methods in pollen analysis. Sven. Bot. Tiddsskr., 30, 154-164.

Fægri, K. \& Iversen, J. 1989. Textbook of Pollen Analysis. John Wiley, Chichester.

Grimm, E. 1992. TILIA and TILIA.GRAPH: Pollen spreadsheet and graphics program. In 8 th International Palynological Congress. Program and Abstracts, p. 171. Aix-en-Provence.

Hicks, S. 1990. Pollen evidence for the activities of man in peripheral areas. Publ. Karelian Inst., Univ. Joensuu, 102, 21-39.

Ilves, E. \& Mäemets, H. 1987. Results of radiocarbon and palynological analyses of coastal deposits of lakes Tuuljärv and Vaskna. In Palaeohydrology of the Temperate Zone III. Mires and Lakes (Raukas, A. \& Saarse, L., eds.), pp. 108-130. Valgus, Tallinn.

Jaanits, L. 1959. Siedlungsplätze des Neolitikums und der Frühen Metallzeit im Mündungsgebiet des Emajõgi. Inst. History, Acad. Sci. Estonian SSR, Tallinn (in Russian).

Jaanits, L. 1968. Sakala asustusest kivi- ja pronksiajal. In Viljandi rajoonis (Maaring, E., ed.), pp. 57-61. Tallinn.

Jaanits, L. \& Ibius, O. 1973. Ajaloost. In Võrtsjärv (Timm, T., ed.), pp. 224-234. Valgus, Tallinn.

Jaanits, L. \& Ilomets, M. 1983. Umbusi mesoliitilise asula vanusest ja kohast Eesti keskmise kiviaja kronoloogias. In Loodusteaduslikke meetodeid Eesti arheoloogias (Rõuk, A.-M. \& Jaanits, L., eds.), pp. 54-63. Inst. History, Acad. Sci. Estonian SSR, Tallinn.

Jaanits, L., Laul, S., Lõugas, V. \& Tõnisson, E. 1982. Eesti esiajalugu. Eesti Raamat, Tallinn. 
Kihno, K. \& Valk, H. 1999. Archaeological and palynological investigations at Ala-Pika, Southeastern Estonia. PACT, 57, 221-237.

Kiristaja, A., Tvauri, A. \& Vindi, A. 1998. 1997. aasta arheoloogilised inspektsioonid. In Arheoloogilised välitööd Eestis 1997, pp. 210-236.

Kriiska, A. 2001. Stone Age Settlement and Economic Processes in the Estonian Coastal Area and Islands. PhD Dissertation. University of Helsinki.

Lagerås, P. 1996. Vegetation and land-use in the Smalånd Uplands, Southern Sweden, during the last 6000 years, LUNDQUA THESIS, 36, 1-39.

Lang, V. 1999. Pre-Christian history of farming in the Eastern Baltic Region and Finland: a synthesis. PACT, 57, 359-372.

Laul, S. \& Kihno, K. 1999a. Prehistoric landuse and settlement history on the Haanja Heights, Southeastern Estonia, with special reference to the Siksali-Hino area. PACT, 57, 239-254.

Laul, S. \& Kihno, K. 1999b. Viljelusmajandusliku asustuse kujunemisjooni Haanja kõrgustiku kaguveerul. Eesti arheoloogia ajakiri, 3/1, 3-18.

Mäemets, H. 1983. Palynological and radiocarbon data on the postglacial vegetational history of Haanja Elevation (ESSR). In Man, Vegetation and Soils (Kurvits, J., ed.), pp. 98-111. Tartu (in Russian).

Moora, H. 1968. Sakala maakonna kujunemine. In Viljandi rajoonis (Maaring, E., ed.), pp. 62-66. Tallinn.

Olsson, I. 1986. Radiometric dating. In Handbook of Holocene Palaeoecology and Palaeohydrology (Berglund, B. E., ed.), pp. 273-312. John Wiley, Chichester.

Orru, M. 1995. Estonian Mires. Handbook. Estonian Geol. Survey. Ramona, Tallinn (in Estonian).

Orviku, K. 1973. Võrtsjärve geoloogilisest arengust. In Võrtsjärv (Timm, T., ed.), pp. 26-32. Valgus, Tallinn.

Pirrus, R., Hang, T. \& Liiva, A. 1993. On the geological development of the Väike-Emajõgi valley and the southern part of Lake Võrtsjärv. Proc. Estonian Acad. Sci. Geol., 42, 28-37 (in Russian).

Poska, A. 2001. Human impact on vegetation of coastal Estonia during the Stone Age. Acta Universitatis Upsaliensis, 652.

Poska, A. \& Königsson, L.-K. 1996. Traces of Mesolithic land-use in a pollen diagram from the Arusoo Mire at Kunda. PACT, 51, 299-309.

Poska, A. \& Saarse, L. 1996. Prehistoric human disturbance of the environment induced from Estonian pollen records. A pilot study. Proc. Estonian Acad. Sci. Geol., 45, 149-164.

Poska, A. \& Saarse, L. 1999. Holocene vegetation and land-use history in the environs of Lake Kahala, Estonia. Veget. Hist. Archaeobot., 8, 185-197.

Punning, J.-M., Koff, T., Ilomets, M. \& Jõgi, J. 1995. The relative influence of local, extra-local, and regional factors on organic sedimentation in the Vällamäe kettle hole, Estonia. Boreas, 24, 65-80.

Saarse, L. 1994. Bottom Deposits of Small Estonian Lakes. Inst. Geol. Estonian Acad. Sci., Tallinn (in Russian).

Saarse, L. \& Harrison, S. P. 1992. Holocene lake-level changes in the eastern Baltic region. In Estonia. Man and Nature, pp. 6-20. Acad. Sci. Estonia, Estonian Geographical Soc., Tallinn.

Saarse, L. \& Rajamäe, R. 1997. Holocene vegetation and climatic change on the Haanja Heights, SE Estonia. Proc. Estonian Acad. Sci. Geol., 46, 75-92.

Saarse, L., Veski, S., Heinsalu, A., Rajamäe, R. \& Martma, T. 1995. Litho- and biostratigraphy of Lake Päidre, South Estonia. Proc. Estonian Acad. Sci. Geol., 44, 45-59.

Saarse, L., Heinsalu, A., Poska, A., Veski, S. \& Rajamäe, R. 1999a. Palaeoecology and human impact in the vicinity of Lake Kahala, Northern Estonia. PACT, 57, 373-403.

Saarse, L., Poska, A. \& Veski, S. 1999b. Spread of Alnus and Picea in Estonia. Proc. Estonian Acad. Sci. Geol., 48, 170-186. 
Stuiver, M., Reimer, P. J. \& Braziunas, T. F. 1998. High-precision radiocarbon age calibration for terrestrial and marine samples. Radiocarbon, 40, 1127-1151.

Tarand, A. \& Kallaste, T. (eds.). 1998. Country Case Study on Climate Change Impact and Adaptation Assessment in the Republic of Estonia. Stockholm Environmental Institute, Tallinn.

Tarvel, E. (ed.). 1993. Henriku Liivimaa kroonika. Olion, Tallinn.

Veski, S. 1998. Vegetation history, human impact and palaeogeography of West Estonia. Pollen analytical studies of lake and bog sediments. STRIAE, $\mathbf{3 8}$.

Veski, S. \& Lang, V. 1996. Prehistoric human impact in the vicinity of Lake Maardu, north Estonia. A synthesis of pollen analytical and archaeological results. PACT, 51, 189-204.

\title{
Taimestiku areng ja inimmõju Parika ümbruses Kesk-Eestis
}

\author{
Eve Niinemets, Leili Saarse ja Anneli Poska
}

On käsitletud taimestiku muutusi Parika raba piirkonnas. Hilis-Glatsiaali lõpul ja Vara-Holotseenis valdasid siin kasemetsad, mis umbes $9000{ }^{14} \mathrm{C}$ aastat tagasi (siin ja edaspidi kõikjal kalibreerimata radiosüsiniku aastad) asendusid kasemänni ja $8000{ }^{14} \mathrm{C}$ aastat tagasi sega- ja laialehiste metsadega. Laialehiste metsade osakaal on olnud väike kogu Holotseeni vältel. Spetsiifilise joonena tuleb esile tõsta vaevakase rohket õietolmu kuni $6000{ }^{14} \mathrm{C}$ aastat tagasi ja märkimisväärset kuuse levikut alates $4800{ }^{14} \mathrm{C}$ aastat tagasi. Parika raba asub nõos, mis hakkas soostuma juba Holotseeni alguses. Turba juurdekasv on kogu selle aja vältel olnud muutlik: suurim viimase 1400 aasta jooksul (1,47-1,60 mm aastas), väikseim $\left(0,40 \mathrm{~mm}\right.$ aastas) $6600-5000{ }^{14} \mathrm{C}$ aastat tagasi. Esimesi inimmõju ilminguid on täheldatud juba mesoliitikumis: ruderaalide õietolmu on oluliselt rohkem. Maastiku avatus suurenes järsult nooremal pronksiajal, kuid esimesed kultuurkõrrelised ilmusid õietolmuspektritesse eelrooma rauaaja lõpul, umbes 2000 aastat tagasi, s.o märksa hiljem kui Põhja-Eestis. Biostratigraafiline materjal lubab oletada, et laiemalt hakati siinseid maid kultuuristama alles 1000 aastat tagasi.

\section{Голоценовые природные и антропогенные изменения в окрестностях Парика, Центральная Эстония}

\author{
Эве Нийнеметс, Лейли Саарсе и Аннели Поска
}

Исследовалось развитие растительности в голоцене в окрестностях населенного пункта Парика - в северо-западной части Выртсъярвеской низменности. В послеледниковый период и в раннем голоцене здесь преобладали густые березовые леса, которые примерно 9000 лет назад (некалибрированные ${ }^{14} \mathrm{C}$ данные) уступили место березово-сосновым, а 
8000 лет назад - смешанным и широколиственным породам, доля которых оставалась скромной на протяжении всего голоцена.

Болото Парика расположено во впадине, заболачивание которой началось еще в начале голоцена, примерно 9500 лет назад. Прирост торфа варьировал от 0,40 мм/год (6600-5000 лет назад) до 1,47-1,60 мм/год (в последние 1400 лет). Первые следы присутствия и деятельности человека в окрестностях Парика отмечены уже в мезолите. На это указывает заметное увеличение количества пыльцы сорняков в палинологических спектрах. Более заметные вырубки леса стали практиковаться примерно 3000 лет назад (во второй половине бронзового века). Выращивание культурных злаков вблизи болота Парика началось примерно 2000 лет назад, т.е. гораздо позднее, чем в Северной Эстонии. Биостратиграфический материал позволяет предполагать, что крупномасштабное окультуривание местности началось лишь 1000 лет назад. 